\title{
Development of Safety Plan Based on Work Breakdown Structure to Determine Safety Cost for Precast Concrete Bridge Construction Projects. Case Study: Girder Erection with Launching Gantry Method
}

\author{
Pungky Dharma Saputra*, Yusuf Latief \\ Department of Civil Engineering, Faculty of Engineering, Universitas Indonesia, Depok, West Java, 16424, Indonesia
}

Received February 25, 2020; Revised May 20, 2020; Accepted May 31, 2020

Copyright $@ 2020$ by authors, all rights reserved. Authors agree that this article remains permanently open access under the terms of the Creative Commons Attribution License 4.0 International License

\begin{abstract}
In Indonesia, there have been many accidents happening in the precast bridges projects. Separate budgets are not specifically provided in implementing OSHMS or Occupational Safety and Health Management Systems. The main purpose of the study is developing safety plan based on work breakdown structure to determine safety cost for precast concrete bridge construction projects. This research is using a survey research method. The respondents are construction safety experts. Descriptive analysis is selected to analyse the variables. The results of the study are safety plan to each hazards and activity, finding the safety costs components based on WBS in order to improve the OHSMS and reduce the rate of accidents. The safety plan is developed based on WBS and can be adapted to determine safety cost components and it can be easier in calculating the real safety costs.
\end{abstract}

Keywords Work Breakdown Structure, Safety Plan, Safety Cost, Precast Concrete Bridge Project, Erection Girder

\section{Introduction}

Indonesia is a large country and one of the most populous countries in the world. The total population reached $261,890,900$ residents, with a population growth rate from 2010 - 2017 of $1.34 \%$ (BPS, 2018). The need for infrastructure is very important for accelerating economic growth. The most important main infrastructure is the transportation sector. Transportation infrastructures are roads and bridges. In order to realize the needs mentioned above, the Government issued a National Strategic Project Acceleration policy regulated in Presidential Regulation
(Perpres) No. 58/2017. Infrastructure development in Indonesia is a major factor in increasing the role of the construction sector in economic development in Indonesia. The number of bridge infrastructure projects that can increase the growth of the construction industry in Indonesia must be supported by precast concrete construction technology. Precast concrete technology in bridge construction is currently experiencing rapid progress and it is used in almost every project in Indonesia. According to Elliot (2016) precast has several advantages, namely easy to build (buildable), cost-effective, and quickly implemented. But this growth was not followed by awareness of the importance of construction safety.

The precast concrete bridge project is part of the construction industry but the construction industry is a dangerous industry (Haadir, 2011; Ramli et al., 2013) and also dangerous business (Wanberg et al, 2013). In the period August 2017 to January 2018, there were taken more than 10 cases of construction accidents in infrastructure projects that left several workers dead and injured (Deny, 2018). When compared with other industries, the construction industry has vulnerabilities and poor safety records (Carter \& Smith, 2006). The hazards and risks of road and bridge construction projects arise due to the different characteristics of each project according to the type of structure, technology, construction methods, location, conditions and environment. So it can be said that the road and bridge project is a difficult, complicated and complex project. This is in accordance with the opinion of Cheng et. al. (2004), one of the factors causing many work accidents is a complicated and complex construction project. The complexity of the construction project can be seen from the construction method used. Jallon et al. (2011) mention that the impacts of work accidents are not only for 
employers and employees but also the nation as a whole (Rohani et al., 2015).

Construction project performance is strongly influenced by the important role of safety management systems (Cheng et al., 2010). The successful implementation of a safety management system at a work site is the result of planning a good safety management system (Ismail et al, 2012). In Indonesia, regulations concerning the safety management system are regulated in the Regulation of Minister of Public Works and Public Housing (Permen PU) No. 05/2014 about occupational safety and health management systems. In this regulation, there are guidelines for creating a safety management system, including safety planning which includes potential hazard identification, risk level assessment, priority scale, safety risk mitigation, and the person in charge. In safety planning, identification of possible potential hazards and risks that can occur as a result of potential hazards is carried out (Rajagukguk, 2019).

Identification of potential hazards is a very important thing to do in a construction project to minimize the occurrence of workplace accidents (Rajagukguk, 2019). Park and Kim (2012) said that in the planning of safety management for effective project completion, an important aspect is to identify risk based on activity (Gurcanli, et al., 2015). The basis of safety planning is a risk based standardized WBS that can help project executor determine the safety performance for each work activity accurately and ensure each activity considering safety requirements (Satrio \& Latief, 2018).

Safety risk control will lead to safety costs (Rajagukguk, 2019). Safety risk control is a part of safety planning that developed from standardized WBS. The safety cost component for each activity can be determined from the WBS-based safety management system so that it can produce a more detailed and accurate safety cost calculation. Then, the safety cost components can be used as a guideline for calculating safety costs on construction projects. And it is very important to define safety cost of a construction project properly, because costs are needed in the implementation of the safety management system. If the costs allocated are sufficient, the application will also increase, and vice versa, the application of the safety management system will experience problems if the allocated budget is lacking. (Rajagukguk, 2019). So, it is very important to develop safety planning based on standardized WBS to determine the safety cost in order to obtain usable output as construction guideline. This study is only limited to the structure of the precast concrete bridge with the erection girder method using launching gantry.

\section{Research Objectives}

The main objectives of this research are:

1. To identify the work package and activity in precast concrete bridge construction projects
2. To identify and to analyze the potential hazards and risk control in each activities of precast concrete bridge construction projects

3. To develop safety plan (specific objective and program) in precast concrete bridge construction projects

4. To identify and to develop safety cost components (safety general cost, safety specific cost, and security cost) in precast concrete bridge construction projects

5. To calculate safety cost in precast concrete bridge construction projects

\section{Literature Review}

In this section, several theories will be discussed which are the results of the literature review used to support this research.

\section{Work Breakdown Structure}

An important way of managing project scope is using WBS (Lei, 2012). Work Breakdown Structure (WBS) is a simplified level of scope of work that flows to be completed by the project team in achieving the required objectives and results. Work package is the lowest level of WBS component that must be planned (PMI, 2017). WBS is a system, where the work packages, components, or elements of WBS are reduced from the project so that it can be arranged to create a general framework that is used in scheduling scope, estimating costs, division of work responsibilities, communication, risk level assessment, supervision and control (PMI, 2006). According to Lei (2012), WBS's main purpose are as a planning and design tool, a structural design tool, a tool for showing projects and instructions and a project status report tool. Project performance measurement on safety planning is based on the results of identification of WBS on deliverables and work packages (Rianti et al, 2018). Integrated planning and supervision support can come from the recommended WBS standardization framework (Makarfi et al., 2009).

\section{Work Package and Activity}

A work package can be used to group activities where work is scheduled and estimated, monitored, and controlled. Work packages are defined as works at the lowest level of WBS where costs and duration can be estimated and managed (PMI, 2017). But according to Suanda (2016) work package is a level where the work components are considered to be sufficient to be managed (planned and controlled) on aspects of cost and time. (Suanda, 2016). The work package is WBS level 4 in precast bridge construction. Project is separated by work breakdown structure into small sections so that activities are more easily managed (Yilmaz \& Kanit, 2018). In the WBS standard the activity level is a complementary level. 
Work activities are WBS level 5 in precast bridge construction. Activities refer to things that the project team do to reach project goals such as testing, programming, etc. (Rad P. F., 1999).

\section{Safety Plan}

A safety plan is a document that contains a plan for practical safety that is used to help companies stay away from potential hazards and can manage these hazards in the best possible way when under these conditions (Elsye, et al., 2018). Safety plan is a very important element of project management. Because the Safety plan covers all health and safety conditions at work, the safety plan not only reduces opportunities for project delays and risk of work accidents, but also increases the potential for success and confidence in team members (PMI, 2017). In safety planning, identification of possible potential hazards and risks that can occur as a result of potential hazards is carried out. Therefore, identification of potential hazards is a very important thing to do in a construction project in order to minimize the occurrence of workplace accidents. (Rajagukguk, 2019). In the Permen PU No. 05/2014, there are guidelines for creating a safety management system, including safety planning which includes potential hazard identification, risk level assessment, priority scale, safety risk mitigation, and the person in charge.

\section{Risk Identification and Risk Control}

In a construction safety management system, identifying safety risks is one of the most important things to do. Risk identification is needed to improve the safety of the workplace. This is the first step to prevent accidents by knowing the risk factors that contribute to accidents. Identification of potential hazards is carried out from each work activity (Rajagukguk, 2019). Park and Kim (2012) said that in the planning of safety management for effective project completion, an important aspect is to identify risk based on activity (Gurcanli, et al., 2015). The next stage after potential hazards are identified, there are potential safety risk control to give an action to the risk in order to decrease the level of safety risk. In the development of a safety management, risk analysis is the foundation while a risk level assessment is forming part of a safety management system (Langford et al., 2000; Low \& Sua, 2000; Cheng et al., 2004; Jung et al., 2008).

\section{Safety Objective}

According to OHSAS 18001: 2007 safety objective and safety program is a measurable goal of an organization's (company) management for safety risk to be achieved. Requirements for preparing safety objectives are shown in clause 4.3.3. OHSAS 18001: 2007, including: (1) Documented, implemented and maintained,
Measurable, applicable and in accordance with the organization's (company) safety Policy, (3) Refers to compliance with safety risks laws and regulations. Permen PU No. 05/2014 mention the safety target divided into two: (1) General Targets: Zero fatal accidents at construction work, (2) Specific Targets: Specific targets are detailed targets of each risk control that are prepared for the achievement of the general Targets

\section{Safety Program}

The company can apply safety programs consisting of elements such as safety planning, safety induction and safety orientation, selection of subcontractor and safety management; this is done to reduce the level of likelihood and severe impact of construction work accidents (Hallowell, 2010). Planned programs for health and safety are designed to avoid work accidents and occupational diseases by taking certain actions. (CCOHS, 2019). The safety program must include the elements required by the minimum health and safety regulations. In Indonesia, Permen PU No. 05/2014 mentions that safety program consists of safety resources, time frame, indicators of achievement, monitoring and person in charge to safety.

\section{Safety Cost}

The main stage in project management is the cost estimation which is carried out during the bidding and tender stages. The basis of project cost is determined by estimating costs at each stage of the project. A contractor will make a cost estimate consisting of general costs, direct costs and project benefits. Then, the results of the estimated costs are submitted to the owner for approval or negotiation (Gurcanli et al., 2015). Safety costs are almost similar to project costs. Many factors affect project costs due to differences in the characteristics of the construction industry so that when the scope expands, the costs will also increase (Gurcanli et al., 2015). But safety costs have never been considered in the estimation of project costs. And the implementation of safety construction was still hampered because of the mindset that safety was an additional cost. As a result, economy becomes the basis for making decisions related to safety and no longer considers ethical and basic rights to work in a safe workplace (Zou \& Sunindijo, 2015). Therefore, it makes economic sense to be considered by the contractor in the prevention of workplace accidents (Dorman, 2000). Actually, in implementing good safety management system, safety cost is needed. Because safety risk control will lead to safety costs (Rajagukguk, 2019).

The Letter of the Minister of Public Works (SE PUPR) No. 11/2019 mentions that costs of construction safety management system are costs of security and occupational health and also construction safety which must be calculated and allocated by the contractors and owners. 
This cost can be called as accident prevention costs. SE PUPR No. 11/2019 shows that safety cost consists of Personal Protective Equipment, Safety Plan, Socialization, Promotion and Training, Working Protective Equipment, Workers Insurance, Environmental Permissions and Licensing, Safety Officer Personnel, Medical Facilities, Infrastructures and Medical Devices, Safety Signs, Consultation with Experts Related to Construction Safety, Others. But based on Regulation of the Minister of Public Works (Permen PUPR) No. 28/2016, safety cost is divided by 3 , i.e. general cost, specific cost and security cost. At the end, defining and determining safety costs in construction projects appropriately are very important in order to be able to calculate safety cost accurately and implementing good safety management system to increase safety project performance.

\section{Method}

This is a survey research. A qualitative approach is used to achieve the objectives of the research. There are 5 stages that are used in this study shown in Figure 1.

\section{Research Variable}

There are 7 research variables which are grouped in to the stages of the research, the variables consist of 6 variables $X$ and 1 variables $Y$ as shown in the Table 1. The variable $\mathrm{Y}$ (safety cost) has 3 sub variables and 11 indicators as shown in the Table 2.

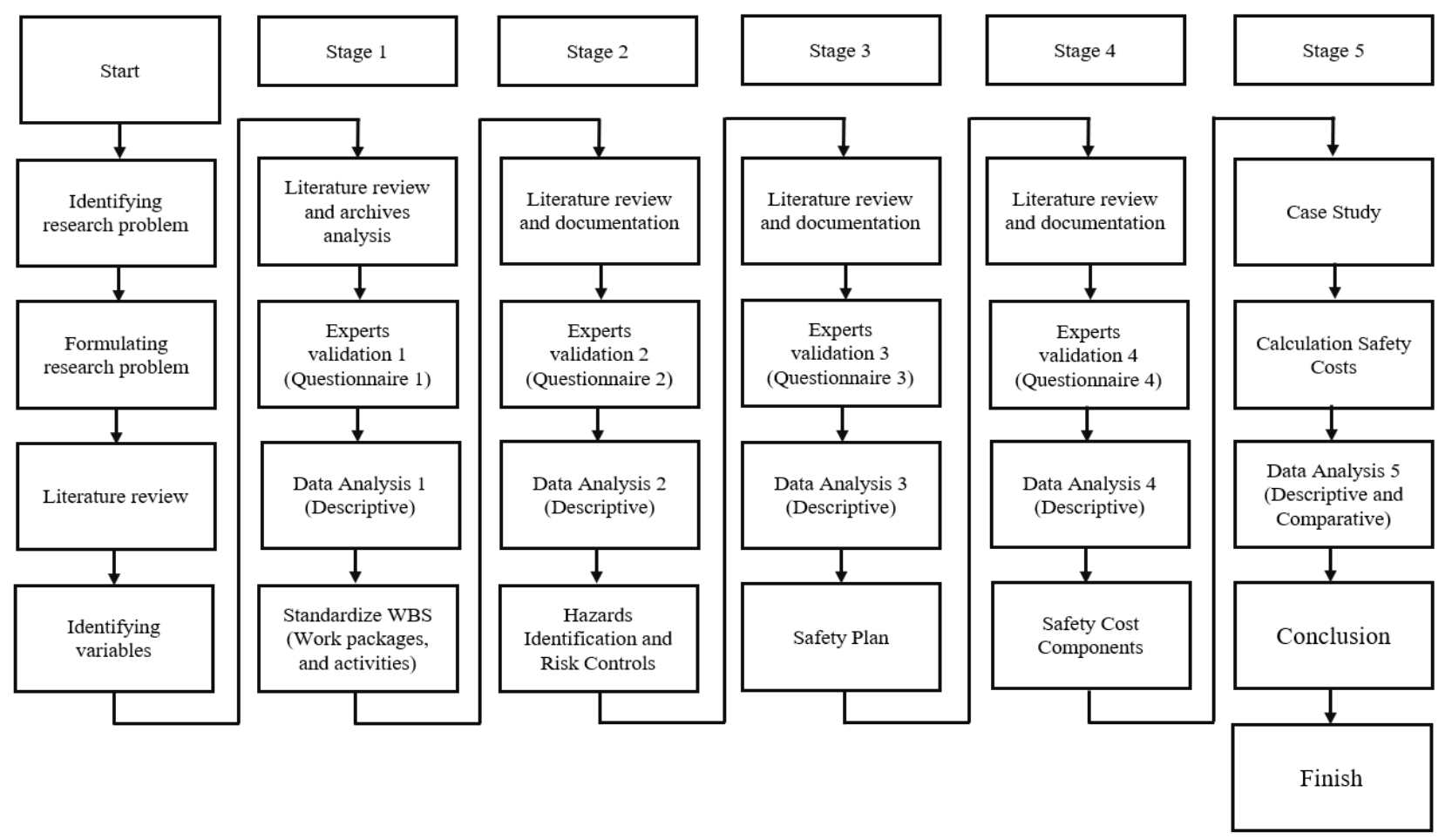

Figure 1. Research Flow Diagram

Table 1. Research Variables.

\begin{tabular}{cccc}
\hline Stage & Code & Variable Name & Reference \\
\hline \multirow{2}{*}{ Stage 1 } & X1 & Work Packages Precast Concrete Bridge WBS & Level 4 \\
& X2 & Activities Precast Concrete Bridge WBS Level 5 & PMI, 2017 \\
\hline \multirow{2}{*}{ Stage 2 } & X3 & Hazard Potential in Precast Concrete Bridge & Permen PU No. 05/2014 \& PMI, 2017 \\
& X4 & Safety Risk Control in Precast Concrete Bridge & PMI, 2017 \\
\hline \multirow{2}{*}{ Stage 3 } & X5 & Safety Specific Target in Precast Concrete Bridge & OHSAS 18001 \\
& X6 & Safety Program in Precast Concrete Bridge & Permen PU No. 05/2014 \\
\hline Stage 4 & Y & Safety Cost & Permen PUPR No. 28/2016 \& SE PUPR No. \\
Stage 5 & & & $11 / 2019$ \\
\hline
\end{tabular}


Table 2. Sub Variables and Indicators Y.

\begin{tabular}{|c|c|c|c|c|c|}
\hline \multicolumn{3}{|c|}{ Sub Variable } & \multicolumn{3}{|c|}{ Indicator } \\
\hline Code & Sub Variable Name & Reference & Code & Indicator Name & Reference \\
\hline Y.1 & General Cost & $\begin{array}{c}\text { Permen PUPR No. } \\
\text { 28/2016 }\end{array}$ & Y.1.1 & $\begin{array}{l}\text { Personal Protective } \\
\text { Equipment }\end{array}$ & $\begin{array}{c}\text { Permen PUPR No. } \\
\text { 28/2016, SE PUPR No. } \\
11 / 2019 \\
\end{array}$ \\
\hline \multirow{9}{*}{ Y.2 } & \multirow{9}{*}{ Specific Cost } & \multirow{9}{*}{$\begin{array}{c}\text { Permen PUPR No. } \\
28 / 2016\end{array}$} & Y.2.1 & Safety Plan & SE PUPR No. 11/2019 \\
\hline & & & Y.2.2 & $\begin{array}{c}\text { Socialization, } \\
\text { Promotion and Training }\end{array}$ & SE PUPR No. 11/2019 \\
\hline & & & Y.2.3 & $\begin{array}{c}\text { Working Protective } \\
\text { Equipment }\end{array}$ & SE PUPR No. 11/2019 \\
\hline & & & Y.2.4 & $\begin{array}{c}\text { Insurance and } \\
\text { Licensing }\end{array}$ & SE PUPR No. 11/2019 \\
\hline & & & Y.2.5 & Safety Personnel & SE PUPR No. 11/2019 \\
\hline & & & Y.2.6 & $\begin{array}{c}\text { Medical Facilities, } \\
\text { Infrastructure and } \\
\text { Devices }\end{array}$ & SE PUPR No. 11/2019 \\
\hline & & & Y.2.7 & Safety Sign & SE PUPR No. 11/2019 \\
\hline & & & Y.2.8 & $\begin{array}{l}\text { Consultation with } \\
\text { Experts Related to } \\
\text { Construction Safety }\end{array}$ & SE PUPR No. 11/2019 \\
\hline & & & Y.2.9 & Others & SE PUPR No. 11/2019 \\
\hline Y.3 & Security Cost & $\begin{array}{c}\text { Permen PUPR No. } \\
28 / 2016 \\
\end{array}$ & Y.3.1 & Security & $\begin{array}{c}\text { Permen PUPR No. } \\
28 / 2016\end{array}$ \\
\hline
\end{tabular}

\section{Questionnaire}

There are 4 stages of questionnaires that are used in this study. Questionnaire 1 is used as instrument to find out the WBS standard used in precast concrete bridge construction with launching gantry method. Questionnaire 2 is used as instrument to identify safety risk based on WBS and to determine the control of the risk. Questionnaire 3 is used as instrument to develop safety plan. Then, questionnaire 4 is conducted to find out cost components needed to carry out control of safety risk based on WBS. Guttman measurement scale is used in each questionnaire in order to get the firm answer "yes" or "no" (Sugiyono, 2018). The data result is nominal data that will be used to analyze.

\section{Respondents}

Respondents in this study are selected with non probability sampling technique (Sugiyono, 2018) and expert judgment (PMI, 2017). In this study, each expert respondent must have requirements to be used as research samples. The requirements of the experts who were asked for their opinions, are as follows:

1. Respondents are experts from three to five people.

2. Respondents have minimum bachelor degree education background

3. Respondents are experienced and experts in the field of Precast Concrete Bridge Work and Construction Safety

4. Respondents are academics, member of professional associations, and practitioners and have a minimum of 10 years professional experience. Practitioners must qualify as a minimum Project Manager, Site Engineering Manager, Site Manager and Safety Manager.

\section{Results of Research and Discussion}

The results in this study are as follow:

1. The development of standardized work breakdown structure for precast concrete bridge construction has been provided from previous research conducted by Kurnia, et al. (2017). This standardized work breakdown structure is confirmed and validated by 5 experts in bridge construction. The Experts will give a judgment whether each level is suitable or not. The Experts not only give a judgment but also a comment to make it more perfect. The result of the expert validation can be reanalyzed. The standardized work breakdown structure of precast concrete bridge which had been validated can answer the research question 1 and the objective is achieved. 


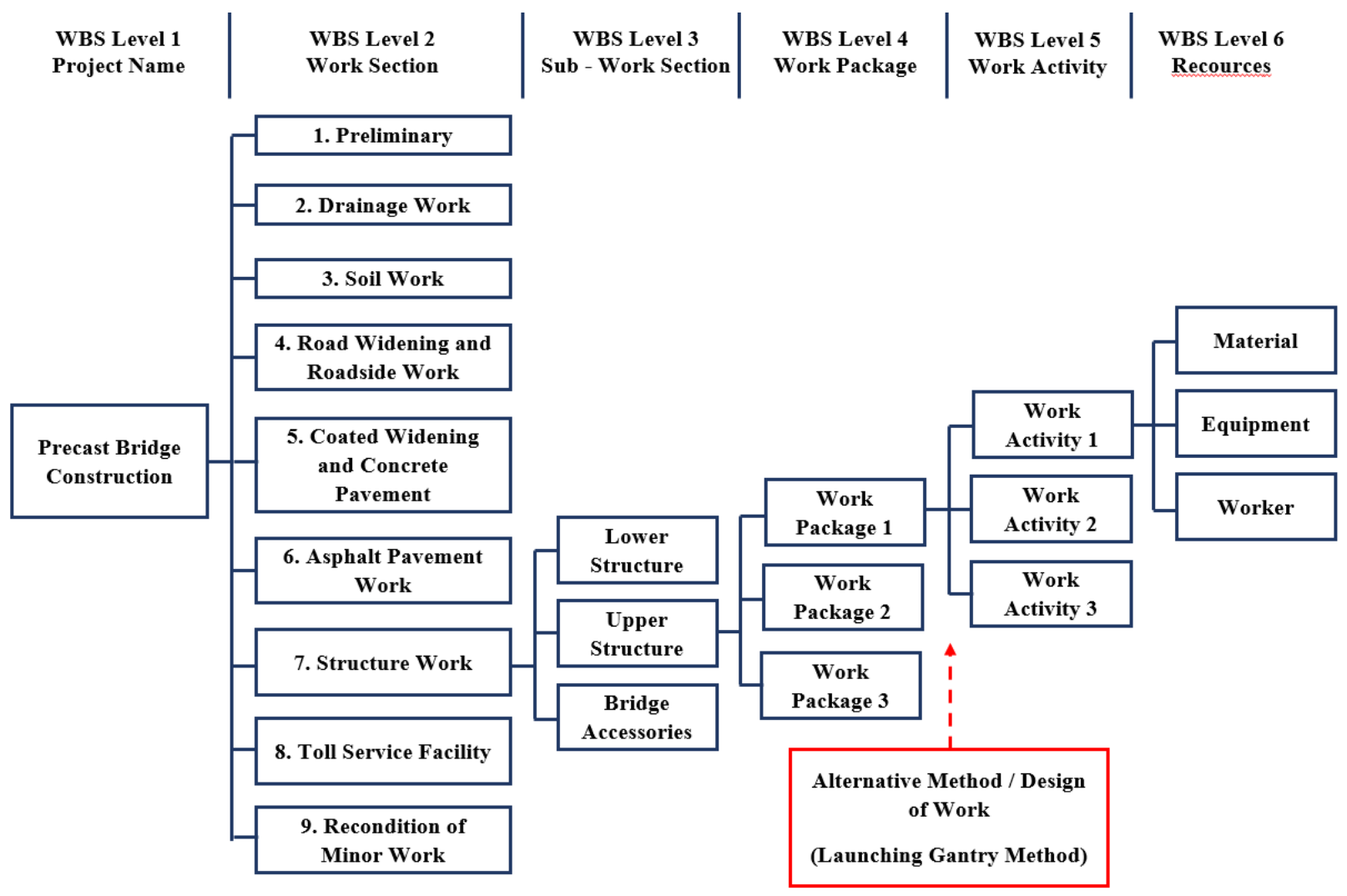

Figure 2. Standardized WBS of Precast Concrete Bridge

Figure 2 above shows the standardized work breakdown structure of precast concrete bridge construction project. This research focus on the upper structure works. The upper structure reviewed is girder erection with launching gantry method. Level 1 is shown as project name. Level 2 shown is as work section, and there are Preliminary Work, Drainage Work, Soil Work, Road Widening and Roadside Work, Coated Widening and Concrete Pavement Work, Asphalt Pavement Work, Structure Work, Toll Service Facility, and Recondition of Minor Work. The results of the standardized work breakdown structure that had been validated will be the basis for identifying safety risks.

2. Work activities and alternative work methods are from the standardized work breakdown structure form the basis for identifying the potential hazards which have influence to safety performance. The potential hazards are identified from the literature review and documentation studies such as project safety plans. After that, the risk controls are determined to reduce the level of risk. The result of this process are confirmed, clarified and validated by the experts. The experts will judge the potential hazards and risk control suitable or not and they will give a comments for further improvement. The result of expert's validation is used to answer research question no. 2 .

3. After identifying potential risk and determining risk control, the next process is developing a safety plan
(RK3K). Safety plan (RK3K) is used to answer the research question no. 3. Based on Permen PU No. 05/2014, safety plan (RK3K) consists of safety specific target and program. Then, the safety plans are validated by the construction safety experts who will give judgments and comments.

4. Safety plan becomes a basis to determine safety cost. Based on Permen PUPR No. 28/2016, safety cost is divided by 3 , i.e. general cost, specific cost and security cost. SE PUPR No. 11/2019 shows that safety cost consists of Personal Protective Equipment, Safety Plan, Socialization, Promotion and Training, Working Protective Equipment, Workers Insurance, Environmental Permissions and Licensing, Safety Officer Personnel, Medical Facilities, Infrastructures and Medical Devices, Safety Signs, Consultation with Experts Related to Construction Safety, Others. Those components must be validated by construction safety experts. And the result can be used to answer research question no. 4.

5. After safety cost components are clearly based on validated safety plan, then actual safety cost can be calculated accurately according to SE PUPR No. $11 / 2019$.

\section{Conclusions}

Research and analysis results obtained from this study 
are:

1. Developing standardized WBS of precast bridges construction consists of 6 levels, Level 1 is Project Name, Level 2 are Work Sections, Level 3 are Sub-Work Sections, Level 4 are Work Packages, (Alternative Methods / Design), Level 5 are Activities, and Level 6 are Resources. Standardized WBS classification level is set after collecting and analyzing data / archives based on previous research and has been validated by bridge construction experts.

2. Identifying several potential risks which exist in work activities and determining the risk responses or risk controls so that the probability and large impact can be reduced.

3. Developing safety plan using making safety plans using risk-based standard WBS prepared and developed based on safety planning documents / Regulation Permen PU No. 05/2014

4. Determining safety cost components based on the safety plan that has been developed, then safety cost components are categorized according to Permen PUPR No. 28/2016 and SE No. 11/2019.

5. Safety cost calculation is based on the determined safety cost components and follows the calculation method stipulated in SE No. 11/2019.

\section{Acknowledgement}

The authors would like to thank the members of the Research Team who have helped researcher who helped the author each in supporting morally and materially in finishing this research.

\section{REFERENCES}

[1] Carter, G., \& Smith, S. D. (2006). Safety Hazard Identification on Construction Projects. Journal of Construction Engineering and Management, 132(2), 197205. doi:10.1061/(asce)0733-9364(2006)132:2(197)

[2] Cheng, C. W., Lin, C. C., dan Leu, S. S. (2010). Use of Association Rules to Explore Cause-Effect Relationship in Occupational Accidents in the Tawan Construction Industry. Saf. Sci. 48, 436-444

[3] Cheng, E. W. L., Li, H., Fang, D. P., \& Xie, F. (2004). Construction safety management: an exploratory study from China. Construction Innovation, 4(4), 229-241. doi: $10.1108 / 14714170410815114$

[4] Dorman, P. (2000). The economics of safety, health and well-being at work: an overview. In Focus Program on SafeWork, International Labor Organization. The Evergreen State College. Retrieved rom http://www.ilo.org.

[5] Elliot, Kim S. (2002). Precast Concrete Structures. Oxford: Butterworth-Heinemann
[6] Elsye, V., Latief, Y., \& Sagita, L. (2018). Development of Work Breakdown Structure (WBS) Standard for Producing the Risk Based Structural Work Safety Plan of Building. MATEC Web of Conferences, 147, 06003.doi:10.1051/mat ecconf $/ 201814706003$

[7] Gurcanli, G. E., Bilir, S., \& Sevim, M. (2015). Activity based risk assessment and safety cost estimation for residential building construction projects. Safety Science, 80, 1-12. doi:10.1016/j.ssci.2015.07.002

[8] Haadir, S. A., \& Panuwatwanich, K. (2011). Critical Success Factors for Safety Program Implementation among Construction Companies in Saudi Arabia. Procedia Engineering, 14, 148-155. doi:10.1016/j.proeng.2011.07.01 7

[9] Hallowell, M. (2010). Cost-effectiveness of construction safety programme elements. Construction Management and Economics, 28(1), 25-34. Doi:10.1080/0144619090346070 6

[10] Ismail, Z., Doostdar, S., \& Harun, Z. (2012). Factors influencing the implementation of a safety management system for construction sites. Safety Science, 50(3), 418-423. doi:10.1016/j.ssci.2011.10.001

[11] Jung, Y., Kang, S., Kim, Y.-S., \& Park, C. (2008). Assessment of safety management information systems for general contractors. Safety Science, 46(4), 661-674. doi:10.1016/j.ssci.2007.06.009

[12] Kurnia, R.F., Latief, Y., \& Riantini, L.S. (2018). The Development of Risk Based Standardized WBS (Work Breakdown Structure) for Cost Estimation of Concrete Precast Bridge Construction. Proceedings of the International Conference on Industrial Engineering and Operations Management Bandung, Indonesia, March 6-8, 2018

[13] Langford, D., Rowlinson, S., \& Sawacha, E. (2000). Safety behaviour and safety management: its influence on the attitudes of workers in the UK construction industry. Engineering Construction and Architectural Management, 7(2), 133-140. doi:10.1046/j.1365-232x.2000.00137.x

[14] Low, S.P., Sua, C.S. (2000). The maintenance of construction safety: riding on ISO 9000 quality management systems. Journal of Quality in Maintenance Engineering, 6(1), 28-44. Doi:10.1108/13552510010311327

[15] Makarfi Ibrahim, Y., Kaka, A., Aouad, G., \& Kagioglou, M. (2009). Framework for a generic work breakdown structure for building projects. Construction Innovation, 9(4), 388405. Doi:10.1108/14714170910995930

[16] OHSAS 18001:2007 Occupational Health and Safety Management System - Requirements

[17] PMI. (2006). Practice Standard for Work breakdown Structure - Second Ed. Project Management Institut, Inc.: Pennsylvania

[18] PMI. (2017). Project Management Body of Knowledge. Project Management Institut, Inc: Pennsylvania

[19] Rad, P. F. (1999). Advocating a deliverable-oriented work breakdown structure. Cost Engineering, 41(12), 35.

[20] Rajagukguk, Steven A. T. M., (2019). Pengembangan Struktur Komponen Biaya Keselamatan dan kesehatan Kerja 
pada Pekerjaan Struktur Bawah Bangunan Gedung Berbasis Work Breakdown Structure pada Proyek Pemerintah. Tesis. Depok: Universitas Indonesia

[21] Ramli, A., Abidin Akasah, Z., \& Idrus Mohd Masirin, M. (2014). Factors Contributing to Safety and Health Performance of Malaysian Low-cost Housing: Partial Least Squares Approach. Research Journal of Applied Sciences, Engineering and Technology, 7(21), 4612-4620. doi:10.19026/rjaset.7.841

[22] Rohani, J. M., Johari, M. F., Hamid, W. H. W., Atan, H., Adeyemi, A. J., \& Udin, A. (2015). Occupational Accident Direct Cost Model Validation Using Confirmatory Factor Analysis. Procedia Manufacturing, 2, 286-290. doi:10.1016/j.promfg.2015.07.050

[23] Satrio, G. \& Latief, Y. (2018). The Development of Risk Based Standardized WBS (Work Breakdown Structure) for Safety Planning of Cable Stayed Bridge Project. Proceedings of the International Conference on Industrial Engineering and Operations Management Bandung,
Indonesia, March 6-8, 2018

[24] Su, Lei. (2012) WBS-based Risk Identification for the Whole Process of Real Estate Project and Countermeasures. National Conference on Information Technology and Computer Science (CITCS 2012) doi:10.2991/citcs.2012.19

[25] Suanda, Budi (2016). Advance Effective Project Management. Jakarta: PP

[26] Sugiyono. (2018). Metode Penelitian Kuantitatif. Bandung: Alfabeta

[27] Wanberg, J., Harper, C., Hallowell, M. R., \& Rajendran, S. (2013). Relationship between Construction Safety and Quality Performance. Journal of Construction Engineering and Management, 139(10), 04013003. doi:10.1061/(asce)co $.1943-7862.0000732$

[28] Yılmaz, M., \& Kanit, R. (2018). A practical tool for estimating compulsory OHS costs of residential building construction projects in Turkey. Safety Science, 101, 326331. doi:10.1016/j.ssci.2017.09.020 